\title{
EXPRESSIVE SPEECH ACTS IN THE STATUSES OF THE FACEBOOK USERS
}

\author{
Widdya Syafitri \\ Andalas University \\ Padang, West Sumatera, Indonesia \\ dzakyam10@gmail.com
}

\section{Abstract}

This research is conducted based on two purposes; they are to identify the types of expressive speech act found in the statuses of the Facebook users, and to explain the modes of expressive utterance used in the statuses. Therefore, the data source is the social network that is Facebook and the data are the statuses of the Facebook users. The data are collected by using observational method, followed by non-participant observational technique and taking-note technique. The data analysis is based on pragmatic identity method proposed by Sudaryanto (2015) which is also supported by the theory of the types of expressive speech act by Ronan (2015), and theory about the modes of utterance from Alwi, et al (2000). The analysis result shows that there are fourteen types of expressive speech act in the statuses. They are the expression of agreement, disagreement, apology, gratitude, sorrow (sadness), exclamation (complaint), volition (hope), anger, disappointment, encouragement, satire, annoyance, pride, and congratulation. Meanwhile, the modes of expressive speech act that are used consist of declarative mode, interrogative mode, and exclamative mode. The importance of this research is to reveal or show that there is something else the Facebook users want to say behind their statuses. Sometimes, they do not really state what they mean in their statuses. They use indirect way and there lies the use of expressive speech act which can be stated in different way.

Keywords: Expressive speech act, types, and modes of utterance

\section{INTRODUCTION}

As we know that language holds important role in communication and it is a medium that connects human with the outside world or the environment. In accordance to one of the language essences, that is instrumentalist, language functions as a device or a mode of communication that conveys messages or purposes to others (Pateda, 2011). Along with the era development and every progress in it, the delivery of information or communication is not only carried from mouth to mouth, but also through some media 
and social media is one of them. The social media itself, which was in the form of television, radio, and newspaper, is now slowly removed by the presence of internetbased social media. In the social media activity, people communicate or convey messages or information for other people. In other words, the information can be seen or known by others easily. Like its name, social media is a medium which enables its users to socialize and to interact with each other, and to share information or establish the cooperation as well (Rohmadi, 2016).

The definition above explains some benefits that can be taken from social media. One of them is a device of getting the information. The information that is provided by social media is very extensive and heterogeneous, from the ordinary things to the trending topics or public talks. Some of the hottest issues or topics that have been discussed lately by the social media users are the topic about the Indonesian government and the country's problems. The discussion about those issues also becomes the trending topics in some social media and Facebook is one of them.

The hottest issues discussed by people on Facebook now are about the government and the country's problem. They cover the increase of health insurance fee, forest fires, and the ratification of some law revisions, namely the revision of the law of Corruption Eradication Commission (Komisi Pemberantasan Korupsi or KPK) and the revision of the Law of Criminal Code (Kitab Undang-Undang Hukum Pidana or KUHP). Regarding those three things, the Facebook users have expressed many of their ideas and opinions on their account. Even, they also comment on other users' statuses that also take up the same the topics. Besides that, some of them just share the issues or news without leaving any comment or caption about the news and sometimes they just post or type an emoticon on their status.

The action taken by the Facebook users is a form of speech act since it is performed by producing an utterance. The research on expressive speech act has been conducted by some researchers, although it still can be counted in its number. Some of them are the researches done by Ronan (2015), Fitria, Revita, dan Asri (2018), and Wulandari, Agustina, and Ngusman (2015). The research that was taken by Ronan focuses on the types of expressive speech act found in the SPICE Ireland Corpus. In another research held by Fitria, Revita, and Asri, it was aimed at finding the types and functions of expressive speech act in Zach Sang show on Youtube. Meanwhile, the research from Wulandari, Agustina, and Ngusman discussed the types, strategies and the situation of the expressive speech act used in Mario Teguh show.

The three researches above show that the focuses of the research are emphasized on the types, function, and strategies of the expressive speech act. What makes them different from this research is that this research not only reveals the types of the expressive speech act, but also the modes of expressive utterance. Besides, this research also uses different source of data, which is a social media (Facebook). Facebook which is used as a medium to communicate and share the information presents or shows a lot of speech act phenomena in it. Therefore, based on that matters and the researcher's curiosity as well 
about the utterances of the Facebook users, especially the expressive speech act, this research is carried out based on two purposes; they are to find out the types of expressive speech act in the statuses of the Facebook users and also to explain the modes of expressive speech acts that are used.

\section{THEORETICAL FRAMEWORK}

Speech act is the action performed by producing an utterance (Yule, 1996). Searle (1979) divides speech act into five categories; they are assertive, directive, commissive, expressive, and declaration. From the five categories, the action conducted by the Facebook users in expressing their ideas and opinions is the form of expressive speech act. Expressive speech act is the expression of feeling and attitude of the speaker. As stated by Searle and Vanderveken (1985) that the expressive point is to express feelings and attitudes. In his book, Searle (1979) also proposes that the illocutionary point of this class is to express the psychological state specified in the sincerity condition about a state of affairs in the propositional content. It means that the point of the expressive speech act is the expression of psychological states of the speaker in term of a condition specified by an appropriate context. In this case, the speaker fits the words with the world or feeling (Yule, 1996). Expressive speech act is used to state or to express the intended feeling so that the utterance will be defined as the evaluation of thing uttered in the utterance (Revita, 2014).

Since its presence, Facebook has shown significant growth in term of the use of internet-based social media, especially in Indonesia (Sulianta, 2015). Facebook is one of social networking services on the internet that can be used to find friends, either new or old friends (Mangkulo \& Solution, 2010). Facebook has been known extensively in the society and has the biggest amount of users among other social media sites. Through Facebook, someone can share a lot of information and discuss many things with friends. Besides its function of finding friends, Facebook also provides the feature of chatting so that it helps its users to communicate or to talk with friends that have been connected to their Facebook account directly.

\section{METHOD}

This research discusses the expressive speech act found in the statuses of the Facebook users. It is a descriptive-qualitative research because it does not use either the percentage calculation or other statistical analysis. In addition, this research also produces descriptive data in the form of spoken or written words from the people or behavior that are being observed. Furthermore, this research also uses natural setting in interpreting the ongoing phenomena (Moleong, 1989). Kuntjojo (2009) also states that the purpose of qualitative research is to understand and to search for the meaning behind the data, and the result of the research is in the form of description and interpretation in certain context of time and situation.

The data of this research are taken from Facebook. The data are the statuses (in the form of written utterances) of the Facebook users. Kesuma (2007) explains that in the data, 
there is the object of the research. Thus, the object of this research is the expressive speech act found in the statuses of the Facebook users.

In gathering the data, the researcher applies observational method with tapping technique as its basic technique. This is because the observational method is always followed by the tapping of the language use either spoken or written form (Mahsun, 2005). In this research, the researcher corresponds with the written form of language use. Therefore, in getting the data, the techniques of the tapping technique are non-participant observational technique and taking-note technique. The non-participant observational technique is applied because the researcher plays a role as the observer of the language use of the informants (the Facebook users), while the taking-note technique is used to note down the forms of the language use corresponding with the research matters found in the statuses. In other words, the taking-note technique is a way of re-writing or transcribing the observation result or all the expressive speech acts found in the statuses of the Facebook users (Kesuma, 2007).

For the data analysis, pragmatic identity method is used (Sudaryanto, 2015). This method aims at identifying the linguistic unit according to the reaction or effect that happen to the interlocutor when the linguistic unit is uttered or conveyed (Kesuma, 2007). In analyzing the data, some theories are taken to support the analysis, they are the theory from Ronan (2015) about the types of expressive speech act and supported by the theory of Illocutionary Force Indicating Devices (IFIDs). IFIDs is a way of determining the illocutionary force of an utterance. In other words, IFIDs can be used to find out what is being conveyed or what the speech act really means (Yule, 1996) while the theory proposed by Alwi, et al (2000) is applied to identify and to explain the modes of the expressive speech acts.

In presenting the result of analysis, the researcher uses informal and formal method. Informal method is the formulation with words to elaborate the conventions used clearly and in detail, while the formal method is the formulation with signs and symbols to give the simpler explanation (Sudaryanto, 2015). Besides that, the use of signs and symbols are more concise.

\section{DISCUSSION}

This research presents the discussion about the expressive speech acts found in the statuses of the Facebook users during September 2019. This is because during the period or month there were some hottest issues or trending topics amidst the Facebook users. As the result of the research, 160 data that contain expressive speech act are found. The data show 14 (fourteen) types of expressive speech act comprising the expression of agreement, disagreement, apology, gratitude, sorrow (sadness), exclamation (complaint), volition (hope), anger, disappointment, encouragement, satire, annoyance, pride, and congratulation. From the fourteen types, the expression of satire is frequently found. Meanwhile, the modes of expressive speech act that are used consist of declarative 
mode, interrogative mode, and exclamative mode and it is dominated by the use of declarative mode. It can be seen as follows:

Table 1. Types of Expressive Speech Act Found in the Status of Facebook Users

\begin{tabular}{|c|c|}
\hline Types of Expressive Speech Act & Total \\
\hline 1. Agreement & 9 \\
\hline 2. Disagreement & 2 \\
\hline 3. Apology & 1 \\
\hline 4. Gratitude & 2 \\
\hline 5. Sorrow (Sadness) & 15 \\
\hline 6. Exclamation (Complaint) & 2 \\
\hline 7. Volition (Hope) & 22 \\
\hline 8. Anger & 14 \\
\hline 9. Disappointment & 10 \\
\hline 10. Encouragement & 12 \\
\hline 11. Satire & 29 \\
\hline 12. Annoyance & 26 \\
\hline 13. Pride & 8 \\
\hline 14. Congratulation & 2 \\
\hline
\end{tabular}

From the table 1 above, it can be seen that the expression of satire dominate the use of expressive speech act in the facebook statuses in term of the three matters. It is frequently found in the statuses because the facebook users feel that the government is ignorant and overlook Indonesian's prosperity. The facebook users think that the policies and the steps taken or implemented by the government will torment and ruin the country. Yet, the problems emerging in the society do not stop the government's pace to ratify and undertake the policies. Besides that, this type of expressive speech act often appears in the statuses because of the distrust of the Indonesian people itself toward the government. The distrust causes the emergence of satire. The distrust reputedly begins from the previous general election in 2014.

Table 2. Modes of Expressive Speech Act Found in the Status of Facebook Users

\begin{tabular}{|c|c|}
\hline Modes of Expressive speech Act & Total \\
\hline Declarative mode & 124 \\
\hline Interrogative mode & 16 \\
\hline Exclamative mode & 20 \\
\hline
\end{tabular}

The dominant mode of expressive speech act found in the Facebook statuses is declarative mode. It is because the expressive speech act is the expression of psychological state of the speaker comprising feelings and also ideas. Therefore, the use of declarative mode is appropriate to use. It can convey the point of the expressive speech act directly. Meanwhile, the interrogative and exclamative mode cannot deliver the expressive speech act to the point. It is the indirect form of the expression in some ways. The following is the 
presentation or discussion about the result of analysis in term of the expressive speech act found in the statuses of Facebook users.

In the datum above, it can be seen the utterance of a Facebook user, that is "Mantjap" which is written after she reads the news about the support given by some lecturers to their college students who participate in the demonstration refusing the ratification of some law revisions, namely the revision of the law of Corruption Eradication Commission (RUU KPK) and the revision of the law of Criminal Code (RUU KUHP). In that news, it mentions the unusual lecturers' attitude towards their students who are absent in the class. Usually, some lecturers would reprimand their students who are not present in the lecturing or miss the class without any information. But in this case or situation, the lecturers allow their students to miss the class and encourage them to get involved in the demonstration as well. In addition, the lecturers will also give their students additional score if they participate in the demonstration and able to make papers about it. The news also encloses some screenshots of Whatsapp short messages sent by the lecturers who supports their student's action.

The utterance written by the Facebook user is a kind of expressive speech act. That is because the Facebook user expresses what she feels and thinks after she reads the news article. Moreover, the utterance that is found in the status is the expression of attitude, opinion, and also feeling of the Facebook user regarding to the topic. In this case, the Facebook user's utterance is a form of her agreement to what is stated by the news. Although the word "mantjap" itself, which is derived from the word "mantap" means firm, steady, and strong (Depdiknas, 2012), but along with the era development language also changes. The word "mantap" can also be used to express feeling or attitude such as the expression of liking, greatness, and others. This speech act is also followed by the use of a thumb emoticon which indicates the liking and agreement toward something.

In uttering the expressive speech act, the Facebook user uses declarative mode. As explained by Alwi, et al (2000) in their book that declarative utterance is used by the speaker or writer to make a statement so that the point of his or her utterance is stating the news to the hearer or reader. In this case, the Facebook user intends to make a statement of her agreement related to the news. Although the word "mantjap" or "mantap" can be categorized into exclamative mode in certain context, but in this case, it belongs to declarative mode due to its type or purpose that expresses an opinion (agreement).

The next datum related to the refusal action of the college students in term of the revision of some laws. Moreover, the data shows the reaction of the Facebook user about the action of the college students who are meeting with some parliament staffs discussing some policies that will be ratified by the government. In that news, it is clearly stated that the chairman of the Student Executive Board from the University of Indonesia is so vibrant and enthusiastic in expressing the students' demands. Although the chairman of the Student Executive Board is facing or meeting the parliament staffs and standing in front of them, it does not dampen his spirit to bring up their demands. 
In that status, it can be seen the use of expressive speech act, that is "Aku padamu diks. Semangat!". That utterance belongs to the expressive speech act because it is an expression of the Facebook user's feeling about the college students' action, specially the action of the chairman. Of the utterance, it can be seen that the Facebook user wants to encourage or support the college students who are involved in the demonstration. The encouragement can be seen from the use of word "semangat" in the status. The word "semangat" itself is used to push the students' spirit so that they do not stop struggling and expressing their demands and Indonesian people in general. Therefore, it can be concluded that the expressive speech act used by the Facebook user here is in the form of encouragement. The encouragement belongs to the expressive speech act because it is related to the expression of attitude or feeling of the speaker about something.

Meanwhile, the mode of utterance used by the Facebook user here is exclamative mode. It can be seen from the use of exclamation mark at the end of the utterance, "semangat". Besides that, the Facebook user through her utterance also delivers something to the students, that is to shout the spirit and support as well and she expects that the students keep struggling for their demands.

Next, the status is related to the actions conducted by the people in term of the matters being faced or encountered by Indonesia and also the policies that are going to be undertaken by the Indonesian government, namely the increase of health insurance fee, forest fires, and the ratification of some law revisions. Those issues trigger pros and cons amidst the society. The parties that refuse or disagree with those issues then conduct the road action or demonstration to deliver their aspiration. As a response to those problems, Indonesian people who were split into two fractions before, when the general election were held in April 2019 because those parties had different political choice, now come together to refuse the policies taken by the government and unite to respond and to overcome the problems faced by the Indonesia at this time. In other words, the Indonesian people become as one in facing the problems.

The status contains expressive speech act that is "Tapi menang pilihan rakyat, kok demo semua". That utterance is the expression of a Facebook user's thought as his reaction toward a status stated that all people demonstrate as their response to the government's policy at this time. In this case, Indonesian people come together and unite so that it removes the fraction that happened before. Moreover, it is stated on the previous election that the selected candidates are the people's choice. Yet, in the demonstration happening now, they unite to reject the policies so that it cannot be seen which party chose the selected candidates in the previous election and which one did not. As the conclusion, the status of the Facebook user is a kind of the insinuation or a statement to satirize the party participating in the demonstration but allegedly chose the selected candidate before.

As to the mode of the expressive speech act, the Facebook user uses interrogative mode. Although the Facebook user does not use or finish his status with any punctuation mark, the interrogative mark still can be found in it that is the word "kok". The utterance of the status "Tapi menang pilihan rakyat, kok demo semua" can be elaborated as follows: 


\section{I Widdya Syafitri}

a. Tapi menang pilihan rakyat.

b. Kok demo semua?

That utterance actually consists of two sentences as separated in a and b. The elaboration focuses on part b. The word "kok" that is placed at the beginning of the sentence is a part of sentence (b) makes the utterance categorized into interrogative mode. It will be different if the word "kok" is placed at the end of the utterance (b) which will change the mode of the utterance to declarative mode because it will bring a statement or assertive function.

\section{CONLUSION}

After observing and analyzing the statuses of the Facebook users, especially concerning the policies that are going to be implemented by the government namely the increase of health insurance fee, forest fires, and some law revisions, it is found the use of expressive speech acts in it. There are numerous statuses or posts related to the latest policies. Yet, some of the Facebook users just re-post or re-share another status that they find on their wall with the emoticon without any caption. The data collected related to the need of this research are 160 data. It is found that there are 14 (fourteen) types of expressive speech act found in the statuses of the Facebook user and 3 (three) modes of expressive utterance. The types comprise the expression of agreement, disagreement, apology, disappointment, encouragement, anger, pride, sorrow (sadness), congratulation, exclamation (complaint), annoyance, satire, gratitude, and volition (hope). As to the modes of expressive speech act, it consists of declarative mode, interrogative mode, and exclamative mode.

\section{REFERENCES}

Ary, D., Lucy Cheser, Jacobs and Asghar, Razavieh. (2010). Introduction to research in education. New York: Wadiworth, Thomson Learning.

Blum-Kulka, Shoshana. (1987). Indirectness and politeness in requests: Same or different?.Journal of pragmatics 11(2), (pp.131-146). North-Holland: Elsevier Science.

Blum-Kulka, Shoshana. (1992). Themetapragmatics of politeness in Israeli society. In R. Watts, S. Ide and K. Ehlich (Eds.), Politeness in language: Studies in its history, theory and practice (pp.255-280). Berlin: Mouton.

Alwi, H., \& dkk. (2000). Tata bahasa baku bahasa Indonesia (ketiga). Jakarta: Balai Bahasa. Depdiknas. (2012). KBBI (Keempat). Jakarta: Balai Bahasa.

Fitria, M., Revita, I., \& Asri, D. (2018). Expressive utterances as found in Zach Sang show on youtube. Vivid: Journal of Language and Literature, 7(1). https://doi.org/http://dx.doi.org/10.25077/vj.7.1.1-12.2018

Kesuma, T. M. J. (2007). Pengantar (metode) penelitian bahasa. Yogyakarta: Carasvatibooks. Kuntjojo. (2009). Metodologi penelitian. Kediri: Universitas Nusantara PGRI.

Mahsun. (2005). Metode penelitian bahasa: Tahapan strategi, metode dan tekniknya. Jakarta: PT. RajaGrafindo Persada. 
Mangkulo, H. A., \& Solution, W. (2010). Facebook for sekolahan. Jakarta: PT. Elex Media Komputindo.

Moleong, L. J. (1989). Metodologi penelitian kualitatif (edisi revisi). Bandung: PT. Remaja Rosdakarya.

Pateda, M. (2011). Linguistik: sebuah pengantar. Bandung: Angkasa.

Revita, I. (2014). Pragmatik: Kajian tindak tutur permintaan lintas bahasa. Padang: FIB Universitas Andalas.

Rohmadi, A. (2016). Tips produktif ber-social media. Jakarta: PT. Elex Media Komputindo.

Ronan, P. (2015). Categorizing expressive speech acts in the pragmatically annotated SPICE Ireland corpus. ICAME Journal, 39. https://doi.org/10.1515/icame-2015-0002

Searle, J. R. (1979). Expression and meaning: Studies in the theory of speech acts. UK:

Cambridge University Press.

Searle, John R., \& Vanderveken, D. (1985). Foundations of illocutionary logic. Cambridge: Cambridge University Press.

Sudaryanto. (2015). Metode dan aneka teknik analisis bahasa: Pengantar penelitian wahana kebudayaan secara linguistis. Yogyakarta: Sanata Dharma University Press.

Sulianta, F. (2015). Keajaiban sosial media. Jakarta: PT. Elex Media Komputindo.

Wulandari, Agustina, \& Ngusman. (2015). Tindak tutur ekspresif Mario Teguh dalam acara golden ways. Jurnal Bahasa, Sastra, dan Pembelajaran, 2(1).

Yule, G. (1996). Pragmatik (terjemahan). Yogyakarta: Pustaka Pelajar.

\section{Online Source:}

www.facebook.com 
10 I Widdya Syafitri 